\title{
A conversation with Lucy Shapiro
}

$\mathbf{L}_{\mathrm{u}, \mathrm{s}}$ cy Shapiro, from Stanford University, is a renowned molecular and developmental biologist whose work has answered the fundamental questions underlying the genetic and molecular decision-making process that directs an asymmetric cell division yielding daughter cells with different cell fates. Shapiro's (Figure 1) insights helped launch the field of systems biology, and more recently, her work has led to the development of novel antifungal drugs. Tune in to the whole interview on the JCI website at: https://www.jci.org/videos/cgms.

JCI: Can you start by telling us about your parents and where you grew up?

Shapiro: I grew up in New York City, the child of Ukrainian immigrants. Although he never had formal schooling, my father taught me to play chess as a young child and instilled in me a love of literature. My mother, a first-generation American, was a music teacher and a pianist. I am the eldest of three sisters. Enid, only 17 months younger than I, was brain damaged at birth. From a very early age, Enid was my responsibility because both my parents worked. Looking back on it, I did not have a carefree childhood.

I was destined to attend my local high school, Manual Training, where only $5 \%$ of the students went on to college. My parents suggested I pursue piano at New York's High School of Music and Art [now called Fiorello LaGuardia High School of Music \& Art and Performing Arts]. Everyone in my family was musical, and I took piano lessons from the age of four. I really wanted to attend Music and Art, but I knew music was not my calling. So I taught myself to draw and took the entrance exam in art. Every night after lights out, I got out a book called How to Draw [Jon Gnagy] that I found at the local library, and with my little flashlight on, I'd go through the book. Fortunately, I had some talent. With my art portfolio in hand, I took the exam and was accepted. It was a family crisis.

I was a good student. I loved math, and I had a biology teacher that really got me intrigued. When it came time for college, there was no way I could leave the city because I was embedded in my family.

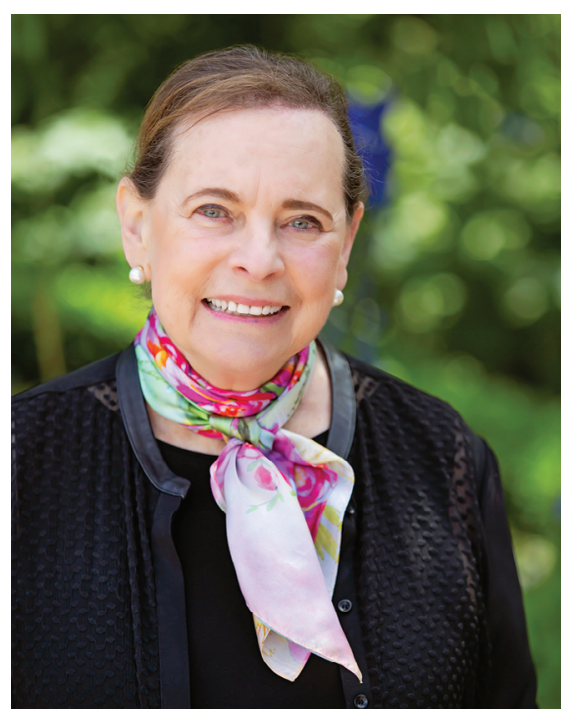

Figure 1. Lucy Shapiro. Photo credit: Christine Baker, Lotus Pod Design.

Brooklyn College was local, free, and had a brand-new experimental program: the Honors Program. I could take anything I wanted, and I didn't have to attend classes, just work with faculty advisors, read, write papers, and pass the finals. I had a double major in fine arts and in biology.

JCI: What did you think you were going to do next?

Shapiro: My goal was to become a medical illustrator, and while in college, I supported myself by illustrating course syllabi. I could have graduated in three and a half years, and near that ending time, I was part of a group art show at Lever House. At the show's opening, I met Ted Shedlovsky, a physical chemist from Rockefeller University. He enjoyed finding creative young people in the arts who he decided would do well in science, and he invited my husband at the time and myself up to Woods Hole for a week. At the end of the time I was there, he urged me to take a course in organic chemistry and then gain experience working in a research lab.

I listened to Ted and dutifully went to the Chemistry Department office at Brooklyn College to see about an organic chemistry course. The only thing available was the

Chairman's Honors Organic Chemistry. The admin wanted to confirm my background in chemistry, and I mentioned signing up for general chemistry, but that I dropped the course. Actually, I had forgotten to drop it officially, so I had to take the final. It was multiple choice, so I circled all the Bs, and I got a D grade. The woman who was listening to me was horrified. Out of his office came the chairman, Dr. Peach. He said, "Now, I'm curious," and asked, "Can you do this?" And I looked him in the eye and said, "I'm very smart." He said, "All right, that's a challenge." That was probably the defining moment in my life.

Organic chemistry was like being exposed to the most beautiful thing I had ever seen. I have an eidetic memory, so if I see a page or write something down, it's like taking a photograph. I can also move molecules around in three-dimensional space easily and see them. Obviously, those abilities are a useful asset for the study of organic chemistry. Next, according to Shedlovsky, I had to find a lab. I applied for several technician jobs. One of them was with Tom August and Jerry Hurwitz at NYU. At that time, Jerry had just codiscovered the DNA-dependent RNA polymerase. Working in that lab was an incredible experience. I remember I shared a bay with Jacques Monod, who had just won the Nobel Prize; he was doing a short sabbatical with Jerry. His experiments weren't working because he continually dripped his cigarette ashes into his test tubes.

JCI: What made you decide to transition from research technician to $\mathrm{PhD}$ student?

Shapiro: We got ahold of the RNA phage F2 that Norton Zinder had just discovered, and Jerry and Tom wanted to know if there was an RNA-dependent RNA polymerase. In another defining moment in my life, I got ahold of the phage, grew it up, and infected E. coli with the F2 phage. After infection, I assayed for the polymerization of radioactive nucleotides into RNA from an RNA template. I remember as though it were today standing in the counting room, and with time after infection, goddamn it, I was making RNA. It was a Saturday, no one was around except Monod, and I ran and pulled him into the counting room, and I said, "That is a new enzyme activity!" And 
Monod said, "Bon. This is indeed very exciting. Now, you must call Professor Zinder and tell him what you've done." Very rapidly after that, Jerry said I should be a graduate student, and that became my thesis. My graduate course work centered on physics, physical chemistry, and biochemistry.

JCI: You headed to a postdoc at Princeton with Walter Kauzmann?

Shapiro: I decided that physical chemistry was what I really wanted to do. Walter Kauzmann at Princeton was doing just really beautiful work, and I didn't apply anywhere else. But just when I was to arrive, he had to go on an immediate sabbatical for family reasons. So I spent about six months in Julius Marmur's lab at Einstein, and at about that time, Bernard Horecker (chairman of molecular biology at Einstein) asked me to come back as a faculty member.

It took me the weekend to say yes. Horecker then did something amazing. He proposed that I take three months to think about what I should do for the rest of my life in science. That was yet another defining moment because it gave me the freedom to think about important questions. I grappled with the idea of positional information: a cell knows where to put things in 3D space. Cellular organization in time and space is inherited. So it must be encoded, but how? How is the information from a genetic code translated into three-dimensional space and remembered?

Also, there are cell divisions that give you cells of different cell fate. Asymmetric division is ultimately the fundamental basis of development and speciation. What do we know about that first asymmetric division in which you have to read the genomes differently in the two cells? Given these questions, I then had to find the right model organism - a cell that was as simple as could be, yet demonstrated positional information that yielded an asymmetric division, every division, and yet could be easily manipulated genetically and biochemically.

JCI: So how did you land on Caulobacter crescentus instead of, say, a polarized mammalian epithelial cell?

Shapiro: I thought that a mammalian cell would be too complicated! In my innocence, I thought a bacterial cell would be quite simple. In my reading, I hit upon Caulobacter, this Gram-negative bug that exhibits polarity and for which every division is asymmetric. When it divides, the resulting daughters have distinct cell fates. Caulobacter had the characteristics I needed, so I sat down and wrote out a plan for the next 20 years of how I was going to dissect this cell from its genome through to every structural and functional change it went through during its cell cycle. I realized that I couldn't possibly just study each of these cell cycle events without understanding how they impacted one another. Clearly, the cell had to be an integrated system operating in time and space, and to me, that was the beginning of systems biology.

JCI: After running departments at Einstein and Columbia, you decamped to California to launch a new department of developmental biology at Stanford.

Shapiro: I remember when I told Richard Axel that I was leaving New York and moving to Stanford, he looked at me and said, "Remember not to breathe any air you can't see." We camped across the countrymy husband is a Texan, and he said, "You've got to see the country." At that time, Harley [McAdams] was a department head at Bell Labs, a physicist. I really was very anxious about this decision to leave New York, but to me, Stanford was a mecca.

Harley got a job working in the aerospace industry dealing with signaling from earth to satellites. At one point, he came to a seminar that Ira Herskowitz gave; at the end of Ira's talk, he had on the board all these genes connected by arrows and bars and feedback loops, and few people could untangle the circuitry except Ira and Harley. By then, my incredible cadre of students and postdocs had worked out a lot of the genetic circuitry that ran the cell cycle and had integrated positional information with regulatory feedback loops. Harley had an aha moment in realizing a cell is run by an integrated system, not unlike electrical circuitry. He was hooked. He joined the faculty at Stanford, and we integrated our labs.

JCI: You served as a White House advisor on bioterrorism - how did that happen?

Shapiro: By 2000, we were facing a perfect storm. Antibiotic resistance was growing rapidly, pathogens were on the move across the globe, and large pharmaceutical houses were not focusing on making new antibiotics or antifungals. I gave as many public talks as I possibly could on antibiotic resistance and the emerging infectious disease threat. Also, I knew the message had to be conveyed to people in powerin Washington, and so I eventually managed to speak with the people who make policy. Furthermore, I founded a biotech company to design novel antiinfectives. As a member of the board of directors of large pharmaceutical firms and biotech companies, I met a visionary biochemist named Steve Benkovic (Penn State). It was with Steve that the plan to build a novel class of small molecules, based on boron instead of carbon at the active site, came to fruition. Steve created a small molecule library, and I tested its activity against an array of cells and pathogens. We had incredible activity that was completely lost if we replaced the boron with carbon. Our very first step was to patent our library. Some were specific for yeast. None touched HeLa cells. Others were effective against different bacterial pathogens: Gram negative and Gram positive. Just at that time [2001], the anthrax scare and everything dealing with bioterrorism was upon us. For Steve and me, that meant that Homeland Security was now very excited by what we had: compounds for anthrax and tularemia and other critical pathogens. Most importantly, our compounds were nontoxic to the host.

We formed a company called Anacor Pharmaceuticals, and it grew into a sizable enterprise. We had on the market the first new antifungal in 50 years with a novel mechanism of action. Another of our drugs was a topical effective in kids that have atopic dermatitis with streptococcus super infection. We did a large trial with children with eczema. It worked okay as an antibiotic for strep infection, but then the docs overseeing the trials reported that the inflammation was going away, in many cases working as well as a steroid ointment. Following a phase III trial with our newly identified PDE4 inhibitor, we sold Anacor to Pfizer, and Eucrisa is now on the market.

We are now focusing our antifungal library on agriculture; we've started a company called Boragen, and it's cooking.

JCI: If you couldn't be a scientist, what else do you think could have kept you engaged for a lifetime?

Shapiro: I love to paint, and I still do. But science is my life. I knew that when I took that first organic chemistry course and then when I met Caulobacter. I simply want to figure out the complete circuitry that makes a living entity. And there is nothing, nothing that I'd rather do other than my science.

\section{Ushma S. Neill}

